This item was submitted to Loughborough's Research Repository by the author.

Items in Figshare are protected by copyright, with all rights reserved, unless otherwise indicated.

\title{
Mapping the Swiss referendum on the minaret ban
}

PLEASE CITE THE PUBLISHED VERSION

http://dx.doi.org/10.1016/j.polgeo.2010.01.008

\section{PUBLISHER}

(c) Elsevier

\section{VERSION}

AM (Accepted Manuscript)

\section{PUBLISHER STATEMENT}

This work is made available according to the conditions of the Creative Commons Attribution-NonCommercialNoDerivatives 4.0 International (CC BY-NC-ND 4.0) licence. Full details of this licence are available at: https://creativecommons.org/licenses/by-nc-nd/4.0/

\section{LICENCE}

CC BY-NC-ND 4.0

\section{REPOSITORY RECORD}

Antonsich, Marco, and Phil I. Jones. 2019. "Mapping the Swiss Referendum on the Minaret Ban". figshare. https://hdl.handle.net/2134/16115. 


\title{
Mapping the Swiss referendum on the minarets' ban
}

\author{
Marco Antonsich and Phil I. Jones \\ School of Geography, Earth \& Environmental Sciences, University of
}

Birmingham, Birmingham B15 2 TT

Political Geography, 29 (2), pp. 57-62.

On November 29, 2009, a clear majority of Swiss people (57.5\%) voted 'yes' to the referendum proposing an absolute ban on the construction of new minarets in Switzerland. This decision has since generated widespread criticism, with various politicians, human right associations, and international organizations (notably the United Nations and the Council of Europe) openly criticizing the initiative and opposing its implementation.

Switzerland is the only country in Europe to have so far legally banned the minarets. Yet, this decision does not seem to be so exceptional when analysed against the ways European countries have recently reacted towards their foreign, and in particular Muslim, populations. In fact, we would argue that the Swiss episode reveals important shortcomings which today characterise, among others, many European countries in their efforts to deal with the ethno-cultural transformation of their populaces. Moreover, the mapping of the results of the referendum invites one to explore further the geographical complexity of the vote. Although these maps reveal 'traditional' electoral cleavages (e.g. rural/urban, rich/poor, etc.), they also reveal unique, place-specific factors. 
The first shortcoming of the assimilation and integration strategies pursued by increasingly multi-ethnic European states relates to the ideological and emotional divide between political institutions and electorate. Just a few months before the referendum, the Federal Council (Switzerland's executive body) invited the Swiss people to vote 'no' (Conseil fédéral suisse, 2009). Three major reasons stood behind this recommendation: legally, the minaret's ban would have violated both international norms concerning human rights and the values of the Swiss Constitution; domestically, it would have risked alienating the Muslim population and causing social tensions; internationally, it would have exposed Switzerland, its people and its economic interests to possible retaliation.

The decision of the Swiss people to go against the recommendation of their political representatives indicates a divide which, regarding migration issues, is hardly confined within Switzerland. The increasing international mobility of people and the ensuing ethnic transformation of contemporary societies have challenged the sociospatial isomorphism between nation and state (Appadurai, 1996). As a way to restore this link, national governments, on the one hand, have tried to incorporate the new ethnically diverse population by reforming their citizenship regimes, stressing the civic rather than the ethnic character of the nation, while at the same time conceding to populist demands for stricter immigration policies (Antonsich, 2009). Public opinion, on the other hand, has reacted defensively towards this transformation, contributing de facto to reproduce an ethnic idea of the nation. In this sense, the Swiss vote, rather than standing alone, is revealing of an ongoing tension between the "postnational' and 'national' tendencies which today affects the nation-state (Ibid.).

Related to this point is a second shortcoming, which we believe characterises the policies that European governments have adopted to deal with the growing ethnic 
diversity of their populations. The general tendency has been to finance programmes aimed at 'integrating' ethnic minorities into the political and social corpus of the nation. In the United Kingdom, for instance, since 2001 the government has created numerous working groups, cross-departmental panels, and ad hoc commissions, which have devised various strategies aimed at integrating Britain's ethnic minorities (Jayaweera and Choudhury, 2008). Yet, the outcome of the Swiss referendum, we would argue, calls for programmes to also 'integrate' the native population within a changing society. Integration should indeed be conceived as a two-way process, which requires change on the part of both ethnic minority individuals and the receiving society (Nagel and Staeheli, 2008). As European countries will become even more diverse in the future (OECD, 2009), the challenge is not merely to integrate or assimilate diversity, but for societies at large to live in (rather than merely with) diversity.

A third element of reflection which emerges out of the Swiss vote concerns Islam and the simplistic way it is often treated in public discourses. To associate a minaret with pro-sharia Islamism - as the proponents of the referendum did (www.minarets.ch) - is manifestly bogus, since there is no evidence to support the case that conservative Islamism is more likely to proliferate in mosques with minarets than in those without minarets. It is also dangerously uncritical, since, rather than discriminating among its many regional, cultural, and religious variants (Ehrkamp, 2005), it simply equates Islam to a single reactionary political ideology, which threatens liberal democracies. Furthermore, it seems likely that supporters of the referendum failed to distinguish between various levels of religious practice among immigrants from predominantly Islamic countries; among the 310,807 Muslims (4.3\% of the total population of the country) who resided in Switzerland in 2000 (year of the 
last census - www.bfs.admin.ch), only a small minority (10-15\%) practiced their religion (Groupe de Recherche sur l'Islam en Suisse, 2005). Combined with the fact that only four minarets existed in the whole Switzerland before the vote, it seems legitimate to affirm that the Swiss vote was less the product of an actual threat stemming from religious practices and more of a general anxiety. This was caused by various factors, both specifics to Switzerland (e.g., the 'opening' of the frontiers under the Schengen Treaty and the political crisis with Libya, following the arrest in Geneva of the son of the colonel Gaddafi in July 2008) and international (e.g., the 'war on terror' and the global financial crisis). In this sense, the uneasiness towards diversity which the Swiss people manifested in the referendum, far from being unique, actually reproduces similar emotive reactions observed in public opinions elsewhere (Brader et al., 2008).

Finally, with the help of a series of maps displaying the results of the referendum against a series of socio-demographic indicators, we would like to suggest that the negative attitude towards (religious) diversity expressed by the Swiss people is associated with a complex geography, which at times refuses the simplifying logic of binary categories (e.g., rural/urban). We are aware that, in the absence of a statistical analysis, any visual representation can offer only an incomplete understanding of an electoral phenomenon. Yet, we hope that the following maps could point to some future directions for additional statistical investigation.

The maps display the distribution of the vote at the commune level, i.e., the smallest geographical unit for which electoral (and census) data are available (unless specified otherwise, socio-demographic data refer to the end of the year 2008). Figure 1 shows the geographical distribution of the vote in relation to language. Traditionally, French-speaking regions have manifested a more leftist political 
behaviour than the German-speaking ones (Bühlmann, 2006). The linguistic map (primary language $\geq 50 \%$ ) seems to confirm this tendency, showing a higher percentage of 'yes' in the German and Italian speaking communes. Interestingly, the multilingual Canton Grisons, where Romansh is also spoken, shows a highly diversified voting pattern.

Religion has played a major role in the nation-building process of Switzerland. In the recent past, the religious divide between Catholics and Protestants remained as a significant political cleavage, with Catholics usually holding more politically conservative views than Protestants (Johnston and White, 1977). This cleavage, however, does not seem to visually emerge from Figure 2 (majority religion $\geq 50 \%$ ): indeed, the vote favouring the banning of the minarets appears transversal across Catholic, Protestant and mixed communes (data refer to the year 2000). Interestingly, also the proportion of Muslims residing in a given commune (Figure 3) does not seem to have affected the vote (also in this case, the datum is for the year 2000). If statistically confirmed, this would be an interesting finding, reflecting a very ideologically charged vote, which would, in turn, challenge the so-called 'contact hypothesis' - i.e., the hypothesis that under certain conditions, interactions between in-group members (dominant group) and out-group members (minorities) cause prejudice towards the out-group to decline (Bowyer 2009).

The rural/urban divide is also one of the traditional cleavages of Swiss politics, with rural areas usually showing inward-looking and conservative attitudes (Linder, 2007). The Swiss Federal Statistics Office divides all the communes into four categories: 1. 'city/town - centre of an agglomeration' (63 cases); 2. ‘commune centre of an agglomeration' (861 cases); 3. ‘isolated town' (3 cases); 4. 'rural commune' $(1,705$ cases). The three categories of the map in Figure 4 have been 
created by merging category 3 with category 2 . The map seems to confirm the rural/urban divide when the major cities (e.g. Zürich, Basel, Geneva, Berne, and Lausanne) are taken into consideration. Yet, this pattern seems less evident when smaller urban settlements are compared with the rural communes. In the case of Canton Ticino, the rural/urban divide does not seem to have played a major role and also in quite a few rural communes of Canton Grisons and other French-speaking cantons this divide does not appear as marked as expected. This finding is obviously subject to how 'urban' and 'rural' are defined, yet the map certainly suggests that further research is required before one can assert the 'common-sense' belief that the differences in regional voting patterns reflect an urban/rural divide.

Given the fact that in today's Switzerland income seems no longer to play a major role in affecting political behaviour (Linder, 2007), it is not surprising that also when people's material conditions are taken into consideration they do not seem to have affected the vote. The map in Figure 5 displays income disparity measured in terms of the Gini coefficient $(0=$ complete equality; $1=$ complete inequality - data refer to the year 2003).

The last three maps show the vote in relation to the political preference given by the population of each commune in the latest election (2007) for the low chamber (National Council). We have aggregated the political parties into three categories: left (PSS, PCS, PES, PEL, Sol, PST, AVF), centre (PRD, PDC, PLS, PEV) and right (UDC, UDF, Lega, DS, PSL). We are aware that this aggregation simplifies the parties' different political positions, yet it has been done for reasons of visual synthesis. 
The three maps in Figures 6, 7, and 8 seem to confirm the expectation that communes voting predominantly for rightist and centrist parties have more willingly supported the referendum than communes voting for leftist parties.

Overall, the maps seem to point to the relevance of some socio-economic and political indicators in explaining the 'yes' vote. Yet, in several other cases the normally relevant socio-economic and political indicators do not appear to be predictive. This finding suggests the importance of context-specific factors and emphasises the importance of place in 'mapping politics' (Agnew, 2002). In other words, prejudice and discrimination are not mere products of certain sociodemographic features, but need to be explored in relation to the complex geographies of place.

\section{Acknowledgements:}

We are grateful to the Swiss Federal Statistics Office (Madeleine Schneider and an anonymous officer), the Swiss Federal Tax Administration (Gema Ricart), and various Swiss colleagues for their help and feedback.

\section{References}

Agnew, J. (2002), Place and Politics in Modern Italy. Chicago: University of Chicago Press.

Antonsich, M. (2009). On territory, the nation-state and the crisis of the hyphen. Progress in Human Geography, 33, 789-806.

Appadurai, A. (1996). Modernity at large. Minneapolis: University of Minnesota Press. 
Bowyer, B.T. (2009). The contextual determinants of Whites' racial attitudes in England. British Journal of Political Science, 39, 559-586.

Brader, T., Valentino, N.A. \& Suhay, E. (2008). What triggers public opposition to immigration? American Journal of Political Science, 52, 959-978.

Bühlmann, M., Nicolet, S., \& Selb, P. (2006). National elections in Switzerland. Swiss Political Science Review, 12, 1-12.

Conseil fédéral suisse (2009). Votation populaire du 29 novembre 2009. Berne: Conseil fédéral suisse.

Ehrkamp, P. (2005). 'We Turks are no Germans': assimilation discourses and the dialectical construction of identities in Germany. Environment and Planning A, $38,1673-1692$.

Groupe de recherche sur l'Islam en Suisse (2005) Vie musulmane en Suisse. Berne: Commission fédérale des etrangers.

Jayaweera, H. and Choudhury, T. (2008). Immigration, faith, and cohesion. York Joseph Rowntree Foundation.

Linder, W. (2007), Political culture. In U.Klöti et al. (eds.), Handbook of Swiss politics (pp. 15-34). Zürich: Neue Zürcher Zeitung.

Nagel, C.R. and L.A. Staeheli (2008). Integration and the negotiation of 'here' and 'there'. Social\&Cultural Geography 9, 415-430.

OECD (2009). International migration outlook. Paris: OECD. 


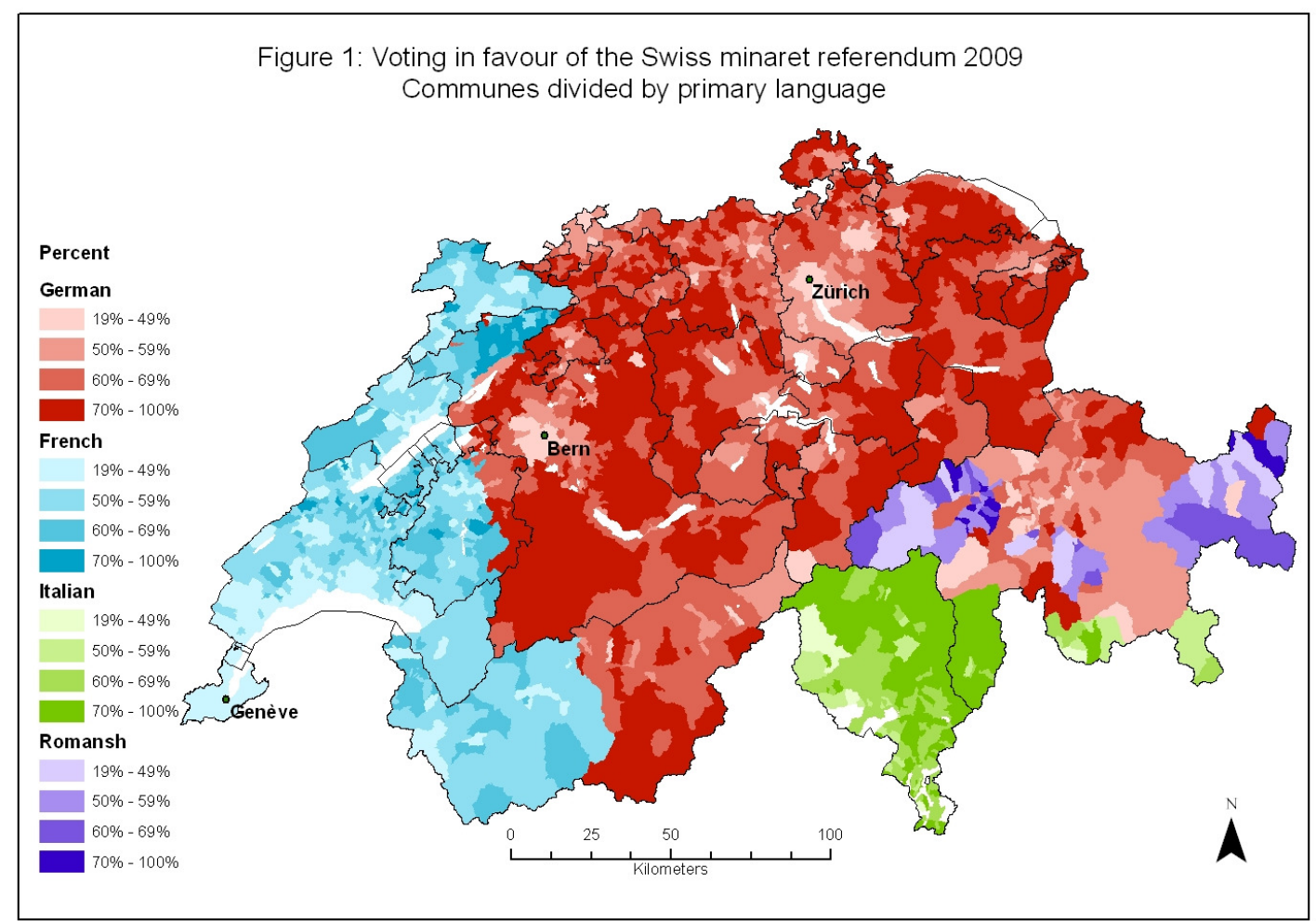

Figure 2: Voting in favour of the Swiss minaret referendum 2009 Communes divided by religious affiliation

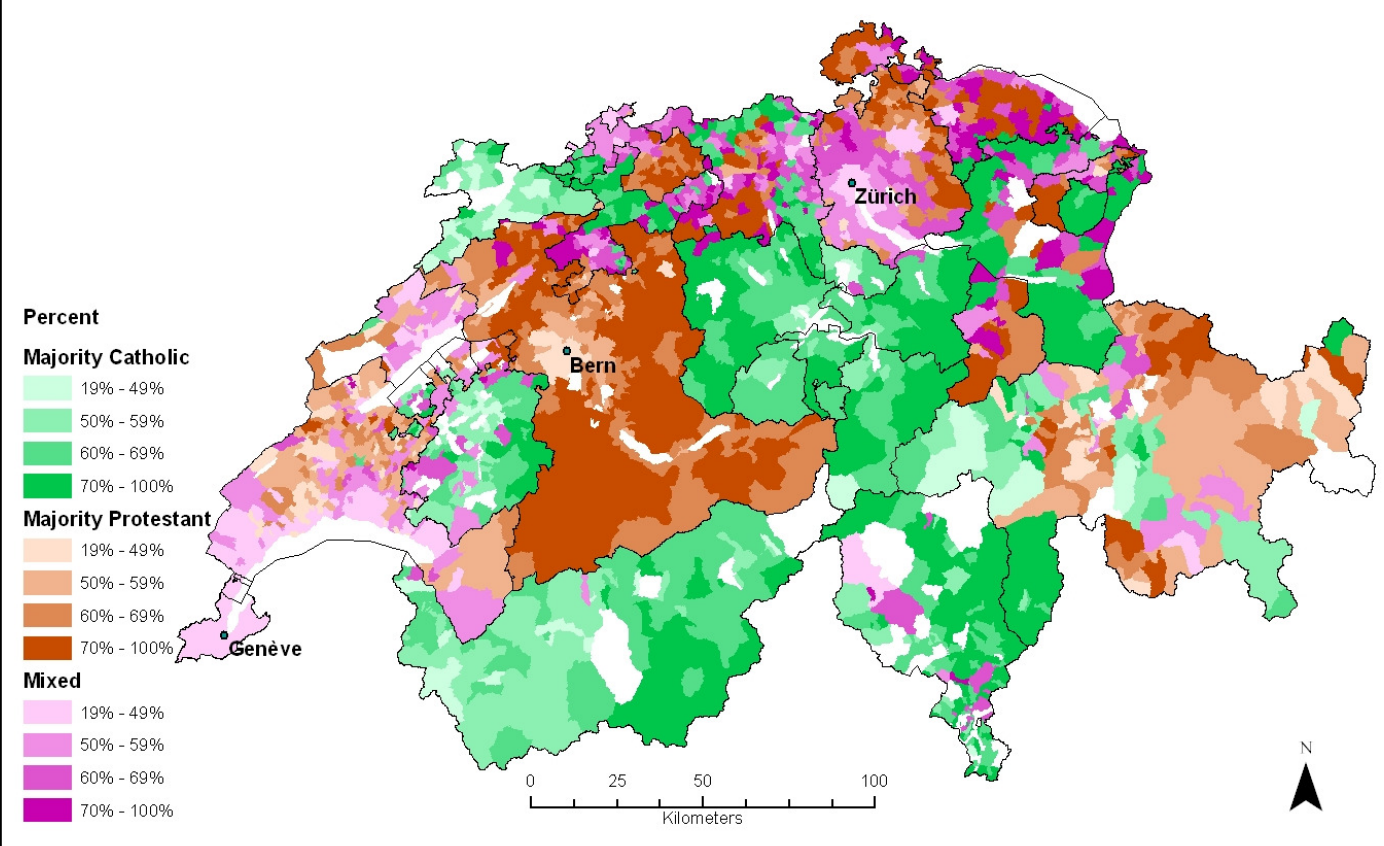



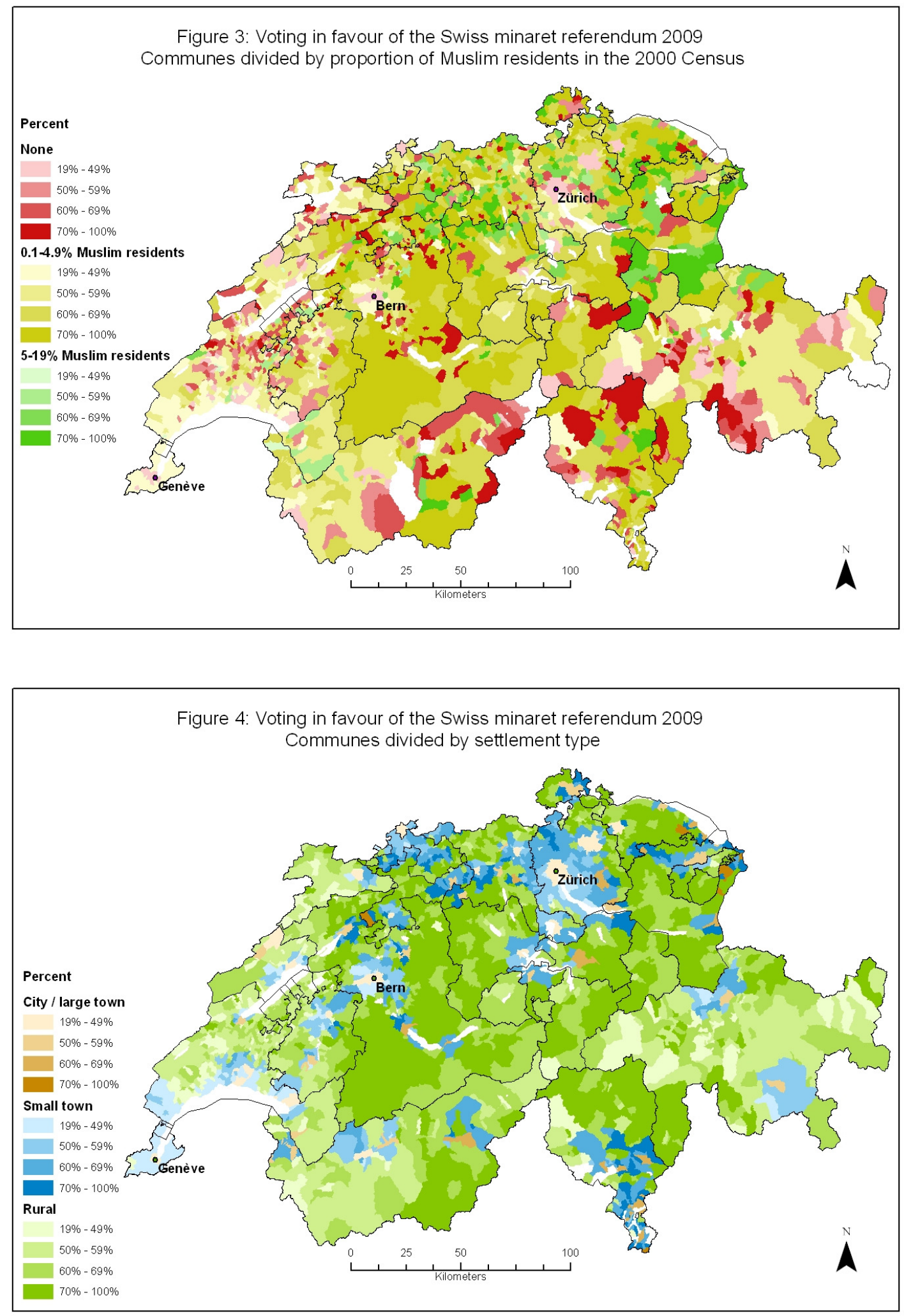


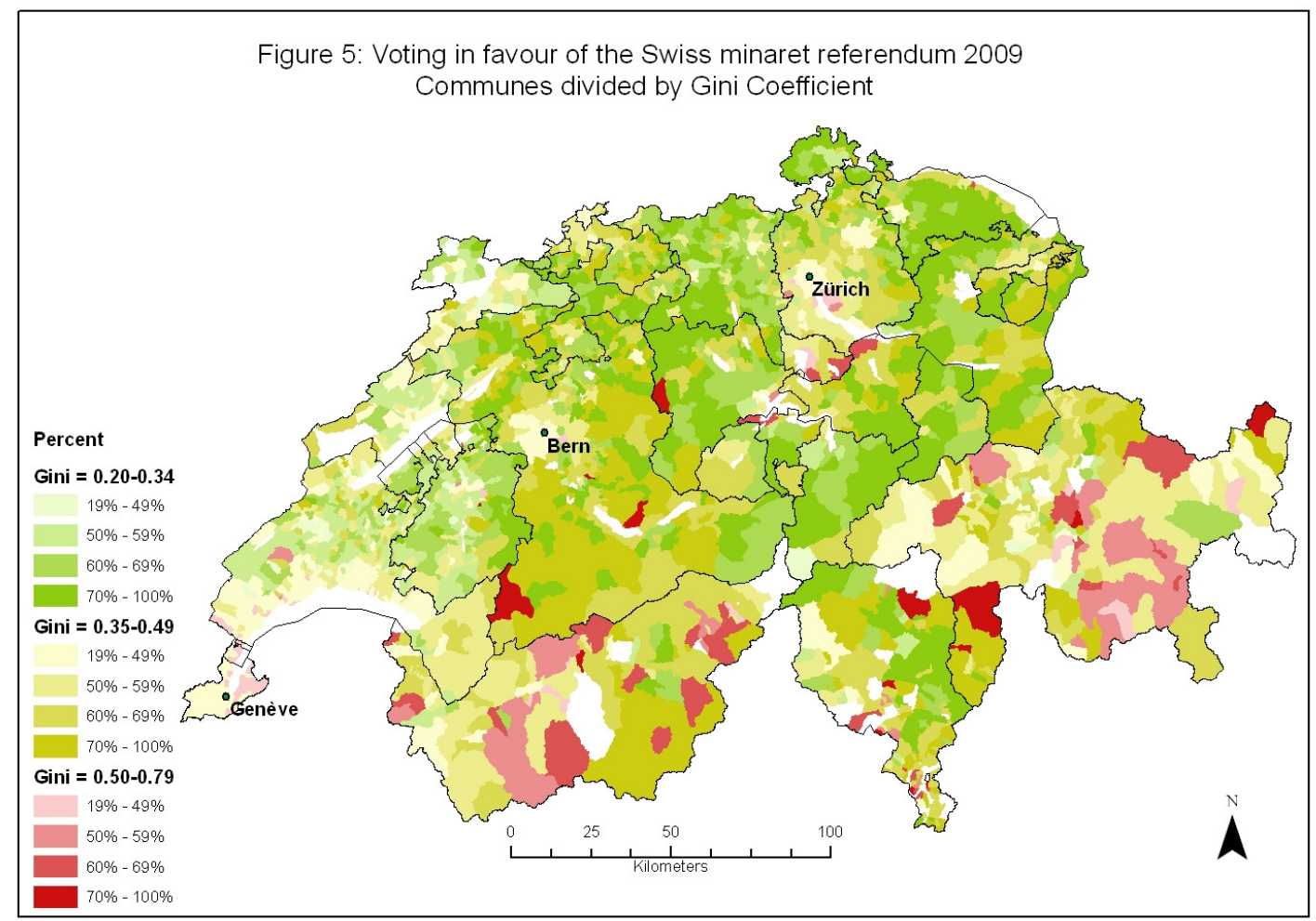

Figure 6: Voting in favour of the Swiss minaret referendum 2009 Communes divided by preference for left wing parties

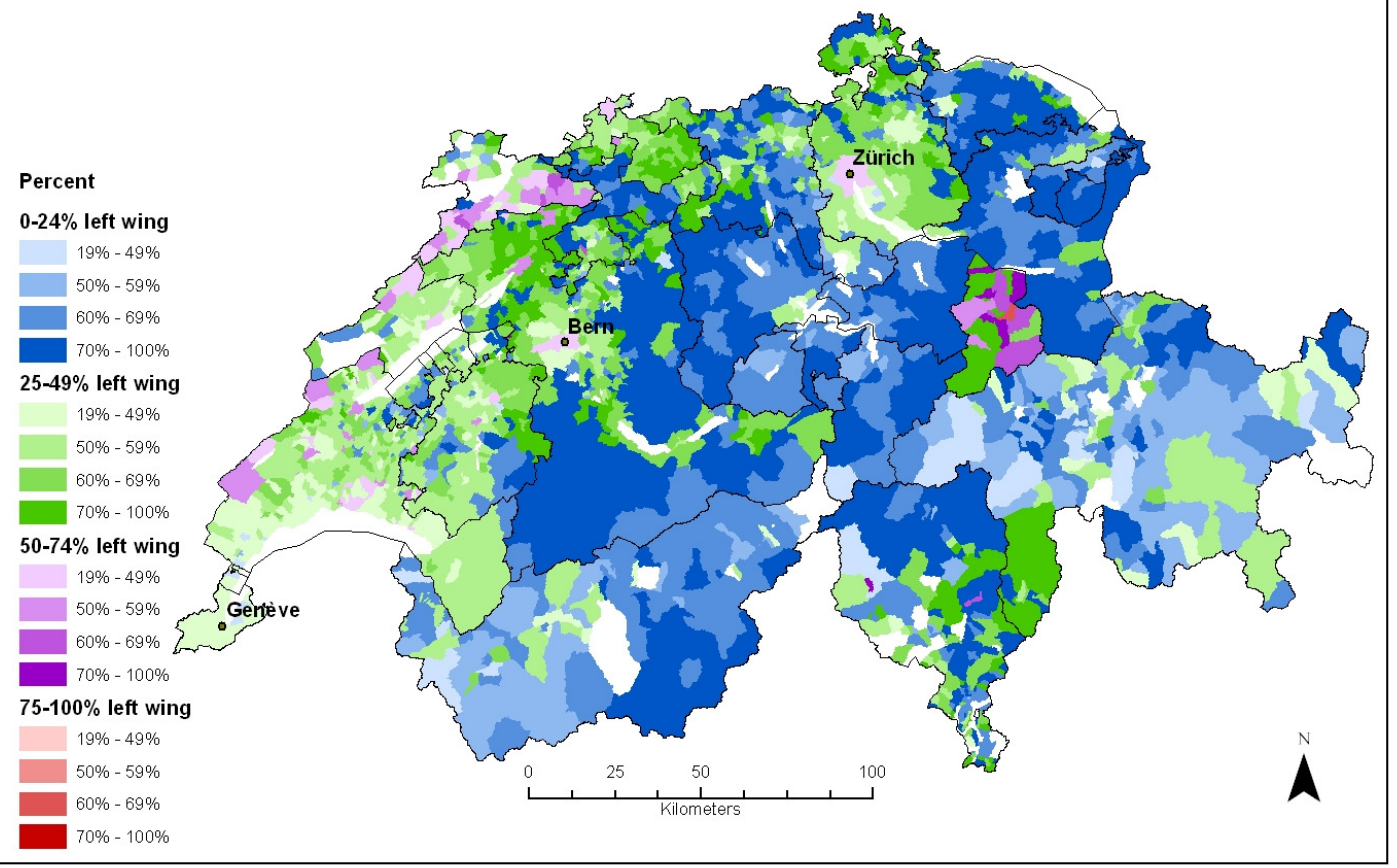



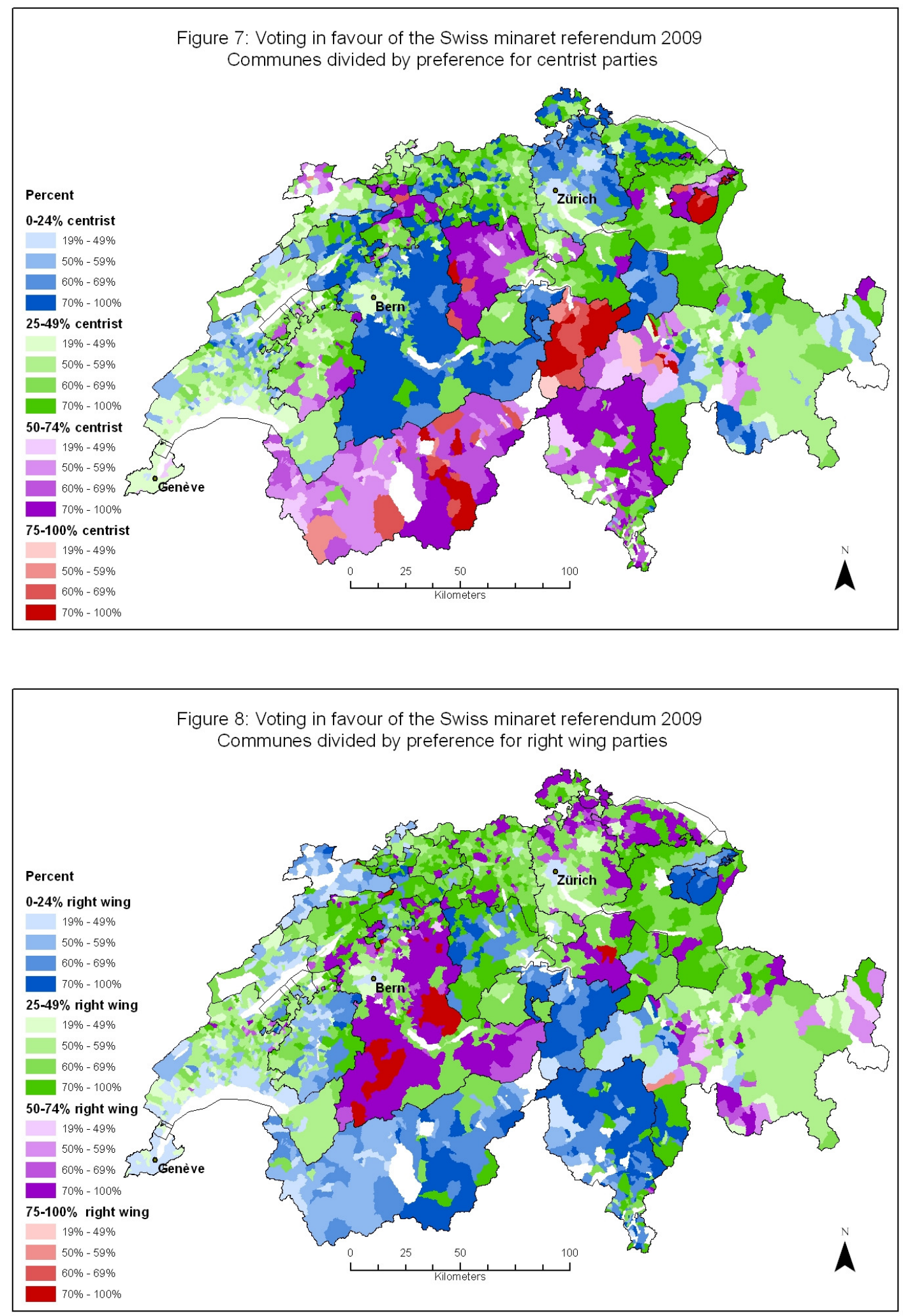